\title{
Military Expenditure and Development: The Economic Linkages ${ }^{1}$
}

\author{
Saadet Deger and Ron Smith
}

Currently, the world is expending vast amounts of resources, both physical and human, on its military effort. Although in total, the bulk of this is accounted for by the industrialised countries, over the last 20 years military expenditure has grown more rapidly in the Third World than in NATO or the Warsaw Pact. This has produced high military burdens (the share of defence expenditure in national income) in many less developed countries (ldcs). The Third World is also the major market for weapons exported by the industrialised countries. Financing these arms purchases imposes considerable cost in terms of scarce foreign exchange and increased indebtedness.

Within the Third World the high levels of military expenditure are linked to pressing security concerns such as regional antagonisms, civil conflicts, and the role of the armed forces in government. Almost all the major conflicts since the Second World War have been fought in the Third World and tens of millions have died in these wars. Military expenditure raises a host of moral, political and social issues, but in this article we shall focus on the economic linkages. Although in many cases the economic dimension is not the most important aspect of the problem, it does play a central role. In addition, after a period of relative neglect, economists have recently become more interested in analysing the effects of military expenditure.

The factual dimensions of defence spending are revealing and they demonstrate that the problem is important. In 1973, the non-oil developing countries spent $\$ 28,518 \mathrm{mn}$ on military expenditure while OPEC spent $\$ 15,707 \mathrm{mn}$ (all figures are in constant 1980 prices and 1980 exchange rate: thus these are volume indices. Data are taken from the Stockholm International Peace Research Institute (SIPRI)). A decade later, in 1982, the respective figures were $\$ 50,810 \mathrm{mn}$ and $\$ 52,903 \mathrm{mn}$. The ldcs had doubled their total defence spending within ten years, a rate of

We are grateful to the ESRC for financial support and to Somnath Sen for comments. growth far in excess of the major Western and Eastern Alliances.

Economic theory does not provide any clear prediction of how a change in the military burden will influence growth, development and welfare. Classical theory would predict, on the basis of resource allocation, that defence will decrease investment or civilian consumption and thus reduce growth or welfare. The military burden would have to be justified on the basis of other social welfare gains such as an increase in collective 'security'. Keynesian theory, on the other hand, could claim that in the presence of inadequate effective demand the operation of the multiplier would imply an increase in national product resulting from additional defence expenditure; thus there could be some economic justification for military spending. If the economy operates with substantial excess capacity then additional demand and output would raise capacity utilisation, thereby increasing the rate of profit and possibly accelerating investment. Whether in the short and long run the former or latter effect dominates will determine the final outcome of defence on growth.

Econometric studies of military expenditures in 14 OECD countries [Smith 1977, 1980] suggest that their major effect is to reduce investment: there appears to be an almost one-to-one correspondence between the shares of military expenditure and investment in the national product [see also Smith and Smith 1983 for a descriptive analysis]. A similar result is reported for the Soviet Union in Green and Higgins (1977). The lower investment induced by higher military expenditure will tend to feed through to lower growth rates. Of course, the growth rate will also be influenced by a wide variety of other factors, which may sometimes offset the impact of military expenditure.

The theoretical case in regard to ldcs is less clear-cut. The basic arguments in terms of unproductive resource allocation and aggregate demand stimulation

IDS Bulletin. 1985, vol 16 no 4. Institute of Development Studies. Sussex 
are still to some extent applicable; but there are 'tropical' twists. It is not at all clear that the effect of a reduction in military spending would filter through to investment and thus growth, for it is highly possible that conspicuous consumption will instead be boosted. Further, in ldcs there are various potential spin-offs (modernisation, work ethos, technical training, discipline etc) emanating from defence spending, that may be helpful in boosting output. If the industrial sector in the developing country suffers from long-term excess capacity due to structural problems (a situation quite common in the newly industrialising nations) a larger defence effort, through additional procurement, might add to output and accelerate growth.

Let us now review in more detail how defence spending may influence the process of development in the Third World. The emphasis is on growth (as well as on some of the major factors that influence it) and the military burden. This is because growth is susceptible to quantification and our major purpose here is to report on empirical research results. However, we also believe that the wider issues of socioeconomic development are crucial for ldcs even though they are not always suitable for econometric analysis, nor always related to growth.

\section{(a) Capital Formation}

To appreciate the role and effect of military expenditure in ldcs it is necessary to understand the nature of the growth process. Growth of national product can be achieved through accumulation of physical and human capital. Thus saving and investment, as well as the mobilisation of human resources, are important and the role of defence in affecting these variables must be noted. There may also be a link between the two, since quite often the productivity of investment is low in developing countries due to absorptive capacity constraints.

Military expenditure may affect capital formation both from the supply and demand side. In the absence of well developed financial markets and the managerial firm, the main supply of new capital comes from household saving and the budgetary surplus of the government (as well as from foreign saving, which is discussed later). Defence expenditure, by providing internal and external security, may change the rate of time preference in favour of saving. Military governments, particularly in times of war, by exhorting the nation to patriotism, may encourage 'forced saving'. However, if threat perceptions rise and instability increases as a consequence of this additional military spending, then saving will fall or be diverted to unproductive forms such as the hoarding of gold.
Military spending may also affect household saving indirectly through the government's reallocation of state budgets. If it reduces the supply of social wage goods, i.e. publicly provided/funded goods, such as education, transport and health services, then private consumption will have to rise to compensate. This in turn may reduce the saving to income ratio. Overall there are strong grounds for believing that defence can reduce the supply of saving and hence adversely affect capital formation.

On the demand side, there is the allocation effect whereby an increase in military spending (or for that matter any other item of government consumption) may reduce investment. However this effect will rarely be one-to-one in ldcs, since other elements of aggregate demand such as civilian government expenditure or the current account surplus might fall.

A more subtle effect on investment will be through absorptive capacity constraints. If cooperating factors, such as technical personnel, infrastructure, vital intermediate imports, craft skills and so forth, are diverted to the military as a consequence of defence spending, then the productivity of investment will drop, causing a reduction in the demand for new productive capital formation. The tightening of such constraints can produce an absorptive capacity drag which can result in lower investment than would otherwise have taken place. On the other hand, counter-arguments would claim that defence has a high productivity enhancement effect, since it contributes to skill formation, technical and vocational training, and the creation of new infrastructural capital.

\section{(b) Human Capital}

Absorptive capacity constraints can be removed or alienated through training and skill-formation, both ingredients of human capital. The military can have both positive and negative effects here; on the one hand it adds to the shock of human capital through its own training programmes which may be useful in civilian life. Alternatively, by possibly reducing government spending on health and education, as well as pulling away skilled people from more 'productive' occupations, it lowers the aggregate productivity of human capital. The final outcome can only be judged empirically [Deger 1981].

\section{(c) Growth}

A major study by Benoit [1973, 1978], seemed to suggest that defence expenditure on balance increases the growth rate in developing countries. There are of course adverse allocative effects; defence is the classic 'unproductive' expenditure. But the sum total of the beneficial channels ultimately succeed in producing a 
positive association between defence and growth leading to development. There is clearly a problem of causality; for it is possible that high growth causes high defence spending. However, the evidence on the whole suggests that military budgets are determined relatively autonomously (dependent on security needs, threat perceptions etc.) and that causation runs from defence to growth [see Deger 1985 for a more complete discussion].

Benoit's work has attracted considerable attention for at least three reasons. His analytical reasoning is persuasive in the sense that there is good economic logic behind the claim that defence can indeed raise growth; although there are also major points against the defence burden and thus the pros and cons need to be rehearsed carefully. Secondly, he adduces econometric evidence in support of his claim; although this also needs to be verified in a more extended empirical model. Thirdly, the analysis shows that the transmission mechanisms of defence efforts to the rest of the economy may be substantially different in ldcs from those in the developed countries. The specific 'structural' characteristics and unique features of developing countries need to be carefully understood before theoretical and empirical judgement can be passed on this issue. Indeed a large part of the Birkbeck research group's work on defence and development has been an attempt to identify the specific channels through which these transmission mechanisms work.

Benoit used a single equation estimate to show that an autonomous increase in defence burden caused a rise in the growth rate and, contrary to expectation, defence raised growth. However, when a more complicated econometric system, utilising the multiple channels that characterise the defence/growth nexus is used the Benoit result is overturned. In various papers [see Smith 1983, Deger and Smith 1983, Deger 1979, Deger 1985] we have shown that taking all interdependent effects together, when the model is estimated by simultaneous equation methods, the overall 'multiplier' shows that an increase in the defence burden reduces the growth rate; and the final value of this negative multiplier is not insignificant. Quite often the direct effect of military spending on growth turns out to be positive. However, almost invariably the defence burden has a high and significantly negative impact on saving (or investment) and human capital, which reduces growth. The sum total of these two influences is an aggregate negative effect. Thus when due account is taken of the underlying simultaneity and interdependences, there seems to be econometric evidence that security spending reduces growth.

\section{(d) Import Cost and Foreign Exchange}

Shortage of foreign exchange is endemic in Third World planning and this is exacerbated by costly weapons imports. For most ldcs a large part of the military equipment budget has to be spent on imported armaments. According to SIPRI, weapons imports by ldcs rose from $\$ 1,559 \mathrm{mn}$ in 1965 to $\$ 10,450 \mathrm{mn}$ in 1980 (all in constant 1975 prices), though they declined to $\$ 9,551 \mathrm{mn}$ in 1983 and $\$ 7,519 \mathrm{mn}$ in 1984 . The latter figure may be affected by the underrecording of recent imports, but even so, it is almost five times larger in volume terms than the arms transferred 20 years ago. Part of the massive rise in the 1970 s was directly at tributable to OPEC revenues. But an important trend over the last decade has been the diminished importance of military aid and the consequent pressure on developing countries to pay in cash or kind.

Weapons purchased with scarce foreign exchange have an obvious allocation cost in terms of reduced resources available for the import of essential intermediate inputs and investment goods essential for self-sustaining growth. It is of course true that a reduction in military imports would not necessarily imply an equivalent increase in investments, for some leakage in terms of conspicuous consumption or other imports could occur. However, there can be little doubt that lower defence imports would improve the situation in terms of foreign exchange scarcity [Deger and Sen 1983b].

From the point of view of national income accounting balances, higher imports, leading to a current account deficit, implies more net saving. Developing countries have tended to be net borrowers in the international capital markets. However, it is one thing to have a high current account deficit attributable to imported capital goods whose marginal productivity is expected to be higher than the interest rate paid. It is quite another to incur trade deficits on the basis of imports of foreign weapons systems which bring in no such economic returns.

As is well known, the 1970s witnessed a large increase in the aggregate indebtedness of the non-oil exporting developing countries. The oil shock, recycling of petro-dollars, greater commercial bank involvement, high nominal interest rates (but low real ones), the import demands of new industrialisation, and the at tainment of upper ceilings on domestic saving, have all contributed to the 'debt problem'. The period coincided, for obvious economic reasons, with the time when defence aid was on the decline, ldcs were being wooed to receive credit-financed arms, exporting countries were using arms exports as a palliative for trade difficulties, and Third World militarisation seemed to be on the increase. It is not 
easy to calculate the extent and contribution of ldc international debt attributable to the military. But Brzoska [1983] estimates that in the latter half of the 1970 s the net transfer of debt would be about 20 to 30 per cent $\mathrm{s}$ ss if debt financed weapons imports had been absent.

\section{(e) Arms Industry}

The foreign exchange burden of weapons acquisition has been reduced to some extent by the use of countertrade (barter) which is becoming more prevalent in this market, particularly for French sales. More important is the fact that some ldcs have developed indigenous arms industries. The initial motivation for establishing an arms industry was often strategic, to gain independence from foreign suppliers. The application of President Carter's human rights policy is said to have been a major incentive for a number of Latin American countries to develop their own weapons. As production expanded economic factors increased in importance, and weapons manufacture came to play a role in both import-substituting and export promoting strategies of industrialisation. It is estimated that about 34 countries in the Third World are producing armaments of one level of sophistication or another.

The pattern of arms production has generally been determined by domestic industrialisation strategies. For economies following import substituting industrialisation arms industries have been built principally as a way of reducing import dependence. Countries under a regime of export promotion have made a concerted effort to manufacture and sell internationally relatively low cost weapons, embodying 'appropriate' technology. India and Argentine in the first group and Brazil and Israel in the second have generally been successful in constructing quite large arms manufacturing bases.

Quantitatively, Third World suppliers still control a relatively small share of the total arms market, but that share is growing rapidly, and the appropriate technology' weapons they sell have some competitive advantages. The success of the Brazilian Embraer design in the UK competition for a basic trainer for the RAF is significant in this respect.

As an economic strategy the benefits of industrialisation through armaments are questionable. It is expensive in terms of domestic resource costs, especially of scarce scientific and technical skills. It depends on extensive imports of components and technology with consequent reliance on arms manufacturers in the industrialised countries. Rapid obsolescence of technology and expensive high risk product development make the returns uncertain.
Because of the prevalence of state subsidies for domestic arms industries the export market is becoming increasingly competitive. When allowance is made for the easy credit terms, offset deals, and co-production agreements which are characteristic of large arms deals, the return on exports may well be less than cost. Given the size of development costs and the increasing returns to scale in arms production, true independence is not possible for any country except the superpowers. It is not surprising that India and Israel are not only among the largest manufacturers of weapons in the Third World, but also among the largest importers.

\section{(f) Government Expenditure}

From Adam Smith onwards defence has been considered the perfect example of a public good. Since security expenditure is monopolised by the state (including arms production in nationalised industries) budgetary allocations are rather crucial in evaluating its role.

Higher military spending may have multiplier effects, particularly if it is concentrated in domestic equipment budgets. It is also possible, with excess industrial capacity, that there are positive interindustrial linkages. Thus demand generation emanating from the military may through increased capacity utilisation expand output, raise the rate of return on capital, induce investment, and increase growth. Such beneficial effects are most probably small in the developing countries, however, whose major problems stem from the supply side.

The financing of defence spending is important. If it raises tax revenue then it is possible for government savings to increase. But once again higher taxes are rarely sufficient to compensate for the additional expenditure, except in special cases of national emergencies. Usually the extra military spending is financed by (bond financed) borrowing, or money creation, or reallocation from other items of spending. Given that the market for securities is weak, the government will go for money financed budget deficits, which in the absence of positive supply side effects are bound to be inflationary. Discussion on Latin American inflation attributes this partly to the defence burden. The impact of inflation on the determinants of growth, however, are not clear-cut, although Deger [1982] reports some detrimental effects.

The third alternative may be the most pernicious. There may be budgetary reallocations in favour of defence and against other items of state spending. We have already discussed the possible reductions in health and education expenditures. But one item very 
easily affected, there being little political lobbying, is government invest ment in agriculture [see Chakravarty 1982]. In terms of aggregate cost-benefits and externalities, it is often claimed that this is one of the most productive avenues of state expenditure in ldcs. Yet agriculture seems to be one of the first casualties when governments embark on defence expansion. There is not very much econometric evidence for this; but what little there is always seems to suggest that an increase in the military burden decreases the share of agriculture in GDP [see Faini, Arnez and Taylor 1984]. This creates many problems: food shortages may appear; expensive imports are necessary; industrial raw materials become costly; demand emanating from the agricultural sector remains depressed; and this has adverse feedbacks on industrial production and capacity; the wage goods constraint becomes more stringent; shortages are exacerbated; and balanced growth remains elusive.

\section{(g) Spin-off}

In addition to these relatively quantifiable effects, various spin-offs have been claimed for defence spending in ldcs. One group can be conveniently summarised under the heading of 'modernisation'. Though the concepts are imprecise they are nevertheless important in the process of growth. In essence the military is expected to change people's attitudes from those relevant to pre-industrial societies towards more modern industrialised ones. The work ethic would be encouraged, discipline instilled, technological awareness heightened, and attitudes towards nation-building fostered. Whether the military establishments actually succeed in doing these things and whether civilian institutions could have done them better, are debatable points and need to be studied in a sociological framework for specific countries.

The other type of claimed spin-off is technological and is also related to arms manufacture. In essence, as technical skills improve, due both to arms use and production, the civilian economy benefits too. Military R \& D can, in the case of dual purpose technology, also help civilian sectors. Military manufactures may also help non-defence sectors by creating inter-industrial demand. However, the opposing arguments are equally valid. Military technology is highly specialised, secretive in nature, 'baroque' in conception, sheltered from market forces, non-competitive in pricing and inappropriate from the point of view of potential demand. Deger and Sen [1983a] using time series data for India found no significant inter-industrial multipliers; thus a much acclaimed expansionary argument for defence seems to be weak.

\section{(h) Wars - the Costs}

The economics of Third World wars is extremely difficult to quantify. 'Hard' data and even simple information is difficult to get, particularly in the mass of propaganda that is thrown out during a war. However, some anecdotal evidence does exist for recent times and Kennedy [1974] has an earlier analysis. It is thought that Israel's relatively long war of 1973 , in 22 days cost it the equivalent of a whole year's income. The economic problems of Argentina in terms of international debt and liquidity are well known. For Pakistan during the period 1969-71, which included the Civil War as well as the war with India, GDP fell by 44 per cent. It has been claimed that Iran's present war with Iraq has inflicted damage to the civilian economy of the order of $\$ 100 \mathrm{bn}$, equal to four years of state revenues including oil. Furthermore this is over and above the pure military costs which are themselves astronomical. Thus wars can hardly be said to be cheap.

The previous sections have indicated the variety of channels through which military expenditure may influence the development process, and the difficulty of making clear theoretical predictions of the impact of military expenditure on other variables. The tractor and tank trade-off is more complicted than intuition seems to suggest. The empirical evidence is a bit more conclusive, but further research needs to be done. The evidence available comes from three main sources. There are general arguments supported by anecdotal evidence and personal experience. There are detailed country studies placing the military in its particular socioeconomic framework. There are econometric studies based on aggregate data on quantifiable variables. The latter approach has been taken by the Birkbeck Group to analyse the relation and the effect of military expenditure (burden) on growth, as well as its macroeconomic determinants such as investment, saving, foreign resources, human capital etc.

These cross-section studies over a large sample of countries (50 in our studies) reveal some underlying pat terns for ldcs taken as a whole. They seem to have identified long term (and possibly stable) parameters. But of course one must be careful in interpreting such data. Fundamental structural changes will cause distortions; and inter-country differences are hidden. In principle cross-section analysis reveals a 'representative' view of the effects of military spending. It can be supplemented by time-series analysis of data for specific countries, but the lack of long series of consistent data may restrict the application of this technique. 
However, our econometric models do suggest that the quantitative evidence supports the hypothesis that defence spending in the Third World does indeed reduce growth through its adverse effect on saving, investment, foreign exchange, human capital and absorptive capacity. There are undoubtedly some positive effects and the role of various spin-offs cannot be denied. But overall, the econometric evidence indicates that military expenditure constitutes a burden and that disarmament presents a major economic opportunity.

\section{References}

Benoit, E., 1973, 'Defence and Economic Growth in Developing Countries', Heath and Co., Lexington Books, Boston, DC

-1978 , 'Growth and defence in developing countries', Economic Development and Cultural Change, vol 26 no 2, pp 271-80

Brzoska, M., 1983, 'The military related external debt of Third World countries', Journal of Peace Research, vol 20 no 3 , pp $271-7$

Chakravarty, S., 1982, 'Notes on disarmament', paper presented at the UNESCO colloquium on Arms Development, Human Rights and Disarmament, Paris

Deger, S., 1979, Economic development and defence expenditure', paper presented at SSRC Development Economics Study Group, London, (forthcoming in Economic Development and Cultural Change, 1985)

-1981, 'Human resources, government education expenditure and military burden in less developed countries', Birkbeck College Discussion Paper No 109, November, (forthcoming in Journal of Developing Areas, October 1985)

- 1982, 'Does military expenditure mobilise resources in less developed countries?', paper presented in the Development Studies Annual Conference, Dublin, (forthcoming in Journal of Economic Studies, 1985)
- 1985, Military Expenditure in the Third World: The Economic Effects, Routledge and Kegan Paul, London

Deger, S. and R. Smith, 1983, 'Military expenditure and growth in less developed countries', The Joumal of Conflict Resolution, vol 27 no 2, pp 335-53

Deger, S. and S. Sen, 1983a, 'Military expenditure, spin off and economic development', Journal of Development Economics, vol 13, August, pp 67-83

$-1983 \mathrm{~b}$, 'Transfer of technology and military expenditure in developing countries', paper presented at the International Economic Association World Congress, Madrid, (forthcoming in Industry and Development, 1985)

Faini, R., P. Arnez and L. Taylor, 1984, 'Defence spending, economic structure and growth: evidence among countries and over time', Economic Development and Cultural Change, vol 32, April, pp 487-98

Green, D. W. and C. J. Higgins, 1977, SOVMOD I: A Macroeconomic Model of the Soviet Union, Academic Press, New York

Kennedy, G., 1974, The Military in the Third World, Duckworth, London

SIPRI, Yearbook of World Armaments and Disarmament, Stockholm International Peace Research Institute (various years)

Smith, D. and R. Smith, 1983, The Economics of Militarism, Pluto Press, London

Smith, R., 1977, 'Military expenditure and capitalism', Cambridge Journal of Economics, March

-1980, 'Military expenditure and investment in OECD countries, 1954-1973', Journal of Comparative Economics, pp 19-32

- 1983, 'Militarausgaben, Ressourcen und Wachstum' in $\mathrm{H}$. Wulf (ed) Aufrustung und Unter-entwicklung, Gesamtherstellung Clausen \& Bosse, Leck, Hamburg 